\title{
Nineteenth Century US African-American and White Female Statures: \\ Insight from US Prison Records
}

\author{
Scott Alan Carson
}

CESIFO WORKING PAPER No. 3169

CATEGORY 4: LABOUR MARKETS

SEPTEMBER 2010

\footnotetext{
An electronic version of the paper may be downloaded

- from the SSRN website:

www.SSRN.com

- from the RePEc website:

- from the CESifo website:

www.RePEc.org

www.CESifo-group.org/wp
} 


\title{
Nineteenth Century US African-American and White Female Statures: Insight from US Prison Records
}

\begin{abstract}
Using a new source of 19th century state prison records, this study contrasts the biological living conditions of comparable US African-American and white female statures during economic development. Black and white female statures varied regionally, and white Southeastern and black Southwestern females reached the tallest statures. White females were consistently taller than black females. Black and white female statures also varied over time with emancipation and were similar to black male stature variation, indicating that 19th century female net cumulative biological living conditions were similar to the lowest ranks of US male society.
\end{abstract}

JEL-Code: I10, I12, J15, J16, N00.

Keywords: Nineteenth Century US Black and White Female Statures.

\author{
Scott Alan Carson \\ School of Business \\ University of Texas, Permian Basin \\ 4901 East University \\ USA - Odessa, TX 79762 \\ carson_s@utpb.edu
}

Please do not cite without permission from the author.

I appreciate comments from participants from Western Social Science Association. Owen Wallace-Servera, Sandy Triepke, Jim Shock, and Anita Voorhies provided excellent research assistance. All errors are mine. 


\section{Introduction}

Industrialization and modernization frequently bring about rising incomes, wages, and life expectancy, particularly in the long run (Komlos, 1985, 1987; Floud, Wachter and Gregory, 1990, pp. 272-273; Margo, 2000; Williamson and Lindert, 1980).

However, in the short run economic change also creates social turmoil, such as increasing inequality, crime, and a more virulent disease environment, which leads to deteriorating biological conditions. Hence, industrialization’s relationship with biological living conditions depends on which effect dominates. A large body of evidence indicates that during the earliest stages of $19^{\text {th }}$ century US industrialization that the net effect on free populations was negative (Margo and Steckel, 1983; Cuff, 2005; p. 216; Carson, 2009, p. 151-154). A persistent yet unanswered question is how female statures and health varied during industrialization and economic development. Female statures may have improved with industrialization when material wealth increased or may have deteriorated if the effects of urbanization and industrialization disproportionately fell on females and young children. This paper, therefore, considers female stature variation during $19^{\text {th }}$ century US industrialization and urbanization.

The use of height data to measure living standards is now a well-established method in economics (Fogel, 1994, p. 138; Strauss and Thomas, 1998; Deaton, 2008; Case and Paxson, 2008). A populations' average stature reflects the cumulative interaction between nutrition, disease exposure, work, and the physical environment (Steckel, 1979, pp. 365-367). When diets, health, and physical environments improve, 
average stature increases and decreases when diets become less nutritious, disease environments deteriorate, or the physical environment places more stress on the body. By considering average versus individual stature, genetic differences are mitigated, leaving only the influence of economic and physical environments on stature. Therefore, stature provides considerable insights into understanding historical processes and augments other $19^{\text {th }}$ century black and white female welfare measures. However, because there was little motivation to record and preserve female statures, our understanding of $19^{\text {th }}$ century US female stature variation remains limited (Komlos, 1992). By using a new source of US prison records, the present study contrasts similar black and white female statures throughout the $19^{\text {th }}$ century.

It is against this backdrop that this paper addresses three questions concerning $19^{\text {th }}$ century African-American and white female statures. First, how did female statures vary by US and international nativity? Black and white US females reached taller statures than females from other countries, and within the US, white Southeastern and black Southwestern females reached the tallest statures. Second, after controlling for both nativity and the physical environment, how did black and white female statures compare by race? Like males, white female statures were consistently taller than their black female counterparts, and there is limited evidence of a female mulatto stature advantage (Steckel, 1979; Bodenhorn, 1999 and 2001; Carson, 2008 and 2009). Third, how did female statures vary throughout the $19^{\text {th }}$ century? Black and white female statures varied with US industrialization and emancipation, and female stature variation was similar to comparable US male stature variation. 


\section{Nineteenth Century US Prison Data}

The data used here to study black and white female statures is part of a large $19^{\text {th }}$ century prison sample. All state prison repositories were contacted and available records were acquired and entered into a master data set. These prison records include Arizona, California, Colorado, Idaho, Illinois, Kansas, Kentucky, Maryland, Mississippi, Missouri, Montana, Nebraska, New Mexico, Ohio, Oregon, Pennsylvania, Philadelphia County, Tennessee, Texas, and Washington (Table 1 ). There are $7,39719^{\text {th }}$ century black and white female observations in the sample. Most black females were imprisoned in the Deep South or Border States-Maryland, Tennessee, and Texas. Most white females in the sample were imprisoned in Pennsylvania, Ohio, and Missouri. The Far West is also represented in the sample.

Table 1, Nineteenth Century US State Penitentiaries

\begin{tabular}{l|cccc}
\hline & \multicolumn{2}{|c}{ Black } & \multicolumn{2}{c}{ White } \\
\hline Prison & $\mathrm{N}$ & Percent & $\mathrm{N}$ & Percent \\
Arizona & 8 & .17 & 12 & .42 \\
California & 8 & .17 & 62 & 2.20 \\
Colorado & 103 & 2.25 & 177 & 6.27 \\
Idaho & 5 & .11 & 12 & .42 \\
Illinois & 51 & 1.12 & 153 & 5.42 \\
Kansas & 26 & .57 & 37 & 1.31 \\
Kentucky & 94 & 2.06 & 37 & 1.31 \\
Maryland & 775 & 16.95 & 289 & 10.23 \\
Missouri & 578 & 12.64 & 354 & 12.54 \\
Mississippi & 182 & 3.98 & 3 & .11 \\
New Mexico & 9 & .20 & 17 & .60 \\
Ohio & 230 & 5.03 & 386 & 13.67 \\
Oregon & 0 & 0 & 5 & .18 \\
Pennsylvania & 238 & 5.20 & 295 & 10.45 \\
Philadelphia & 428 & 9.36 & 741 & 26.24 \\
Tennessee & 903 & 19.75 & 161 & 5.70 \\
Texas & 935 & 20.45 & 83 & 2.94 \\
\hline Total & 4,573 & 100.00 & 2,824 & 100.00 \\
\hline
\end{tabular}


Source: Data used to study black and white anthropometrics is a subset of a much larger $19^{\text {th }}$ century prison sample. All available records from American state repositories have been acquired and entered into a master file. These records include Arizona, California, Colorado, Idaho, Illinois, Kansas, Kentucky, Missouri, New Mexico, Ohio, Oregon, Pennsylvania, Texas, Utah and Washington.

Notes: Stature is in centimeters. The occupation classification scheme is consistent with Ferrie (1997).

All historical stature data have various biases, and prison and military records are the most common source of historical stature data. Since $19^{\text {th }}$ century females were not soldiers, few institutions had a reason to record female statures (Fogel et al, 1978, p. 85; Sokoloff and Vilaflor, 1982, p. 457, Figure 1). Fortunately, prison records consistently enumerated female statures with their characteristics. However, the prison records are not above scrutiny, such as being drawn from lower socioeconomic groups, that segment of society most vulnerable to economic change (Bogin, 1991, p. 288; Komlos and Baten, 2004, p. 199). This selectivity is acceptable, because $19^{\text {th }}$ century females' occupied social positions little higher than black males and other minorities. For height as an indicator of biological variation, the $19^{\text {th }}$ century US female prison data creates an untapped source for black and white female statures that until the present study have remained unexamined. 
Between 1812 and 1922, prison officials routinely recorded the dates inmates were received, age, complexion, nativity, height, pre-incarceration occupation, and crime. Physical descriptions were recorded by prison enumerators at the time of incarceration as a means of identification, therefore, reflect pre-incarceration conditions, and all records with complete age, stature, occupations, and nativity were collected. There also is concern over entry requirements, and arrests and prosecutions across states may have resulted in various selection biases that may affect the results of this analysis. However, black and white male stature variation in U. S. prisons is consistent with other stature studies (Steckel, 1979; Margo and Steckel, 1982; Nicholas and Steckel, 1991, pp. 941943; Komlos, 1992; Komlos and Coclanis, 1997; Bodenhorn, 1999; Sunder, 2004). Because the purpose of this study is $19^{\text {th }}$ century female statures, males are excluded from the analysis. ${ }^{1}$

African and European Americans within the $19^{\text {th }}$ century US were from two prominent racial groups. Fortunately, inmate enumerators were quite thorough when recording inmate complexion, birth, and nativity. For example, enumerators recorded inmates' race in a complexion category, and African-Americans were recorded as black, light-black, dark-black, and various shades of mulatto (Komlos and Coclanis, 1997). Enumerators recorded white complexions as light, medium, dark, and fair. The white inmate complexion classification is further supported by European immigrant complexions, who were always of fair complexion and were also recorded as light,

\footnotetext{
${ }^{1}$ We also do not know the degree to which each state housed males with females. However, existing records suggest males and females were kept separately.
} 
medium, and dark in US prisons. ${ }^{2}$ While mulatto inmates possessed genetic traits from both European and African ancestry, they were treated as blacks in the $19^{\text {th }}$ century US and when comparing whites to blacks, are grouped here with blacks.

Because the youth height distribution is itself a function of the age distribution, a youth height index is constructed that standardizes for age to determine if female youth statures were distributed symmetrically and whether there were arbitrary truncation points imposed on inmate stature either by law enforcement or state legislation. The ageadjusted youth stature index is calculated by first calculating the average stature for each age group; each observation is then divided by the average stature for that relevant age group (Komlos, 1987, p. 899). Figure 1 demonstrates that black and white female statures were distributed symmetrically and there is little evidence of age heaping or arbitrary truncation points.

\footnotetext{
${ }^{2}$ I am currently collecting $19^{\text {th }}$ century Irish prison records. Irish prison enumerators also used light, medium, dark, fresh and sallow to describe white prisoners in prisons from a traditionally white population. To date, no inmate in an Irish prison has been recorded with a complexion consistent with African heritage.
} 
Figure 1, Nineteenth Century Black and White Youth and Adult Stature Histograms
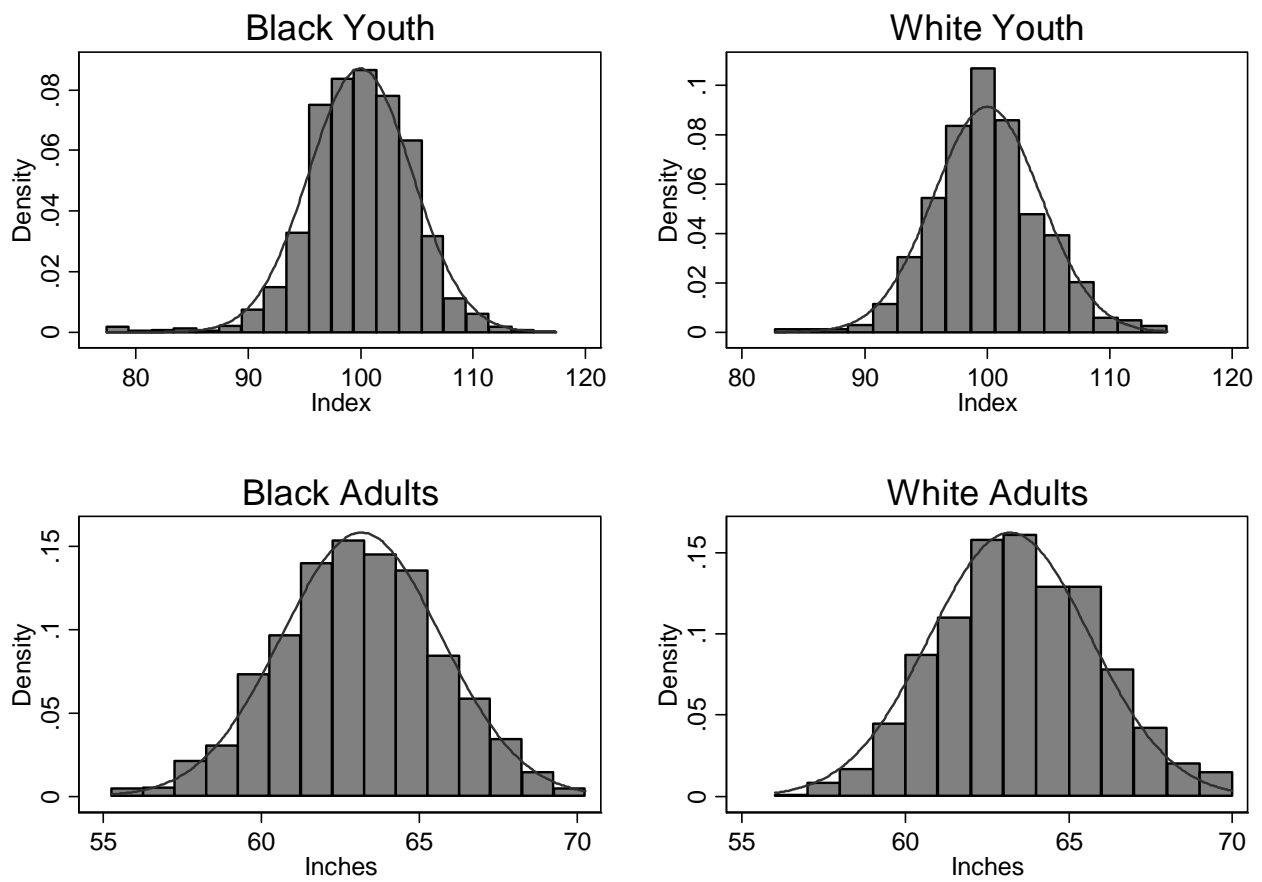

Source: See Table 1. 
Table 2, National Prison Data White and Black Female Descriptive Statistics

\begin{tabular}{|c|c|c|c|c|c|c|c|c|}
\hline & White & & & & Black & & & \\
\hline Ages & $\mathrm{N}$ & Percent & Mean & S.D. & $\mathrm{N}$ & Percent & Mean & S.D. \\
\hline Teens & 417 & 14.77 & 159.08 & 6.80 & 1,410 & 30.83 & 158.63 & 7.27 \\
\hline $20 s$ & 1,213 & 42.95 & 160.67 & 6.83 & 2,256 & 49.33 & 160.13 & 7.01 \\
\hline $30 s$ & 719 & 25.46 & 161.10 & 6.75 & 616 & 13.47 & 160.70 & 7.28 \\
\hline $40 \mathrm{~s}$ & 330 & 11.69 & 159.69 & 6.39 & 202 & 4.42 & 159.88 & 7.29 \\
\hline $50 \mathrm{~s}$ & 102 & 3.61 & 160.47 & 6.68 & 65 & 1.42 & 160.26 & 7.15 \\
\hline $60 s$ & 43 & 1.52 & 157.74 & 7.29 & 24 & .52 & 159.94 & 7.12 \\
\hline \multicolumn{9}{|l|}{ Birth } \\
\hline \multicolumn{9}{|l|}{ Decade } \\
\hline 1770s & 49 & 1.74 & 158.17 & 6.90 & 44 & .96 & 158.65 & 5.12 \\
\hline $1780 \mathrm{~s}$ & 64 & 2.27 & 159.04 & 6.56 & 70 & 1.52 & 158.28 & 7.61 \\
\hline 1790s & 86 & 3.05 & 159.90 & 6.40 & 180 & 3.94 & 158.73 & 6.64 \\
\hline $1800 \mathrm{~s}$ & 45 & 1.59 & 159.36 & 7.83 & 215 & 4.70 & 157.78 & 6.31 \\
\hline 1810s & 84 & 2.97 & 159.62 & 7.56 & 175 & 3.83 & 157.41 & 7.15 \\
\hline $1820 s$ & 150 & 5.31 & 158.90 & 6.68 & 129 & 2.82 & 157.78 & 7.29 \\
\hline 1830s & 263 & 9.31 & 159.02 & 6.32 & 139 & 3.04 & 158.29 & 7.25 \\
\hline $1840 \mathrm{~s}$ & 492 & 17.42 & 159.75 & 6.65 & 353 & 7.72 & 158.49 & 7.91 \\
\hline $1850 \mathrm{~s}$ & 483 & 17.10 & 159.88 & 6.96 & 517 & 11.31 & 158.39 & 8.06 \\
\hline $1860 \mathrm{~s}$ & 353 & 12.50 & 161.44 & 6.26 & 612 & 13.38 & 160.24 & 6.88 \\
\hline 1870s & 359 & 12.71 & 161.80 & 6.48 & 965 & 21.10 & 161.01 & 7.07 \\
\hline 1880s & 264 & 9.35 & 162.28 & 6.80 & 829 & 18.13 & 160.78 & 6.78 \\
\hline $1890 \mathrm{~s}$ & 132 & 4.67 & 161.04 & 7.64 & 345 & 7.54 & 160.69 & 6.22 \\
\hline \multicolumn{9}{|l|}{ Nativity } \\
\hline North East & 50 & 1.77 & 160.33 & 6.45 & 15 & .33 & 158.88 & 6.07 \\
\hline Middle & 944 & 33.43 & 159.54 & 6.20 & 1,344 & 29.39 & 157.49 & 7.02 \\
\hline \multicolumn{9}{|l|}{ Atlantic } \\
\hline Great Lakes & 503 & 17.81 & 161.79 & 7.21 & 183 & 4.00 & 160.15 & 6.05 \\
\hline Plains & 279 & 9.88 & 162.32 & 6.76 & 446 & 9.75 & 161.25 & 7.14 \\
\hline Southeast & 412 & 14.59 & 162.33 & 6.85 & 1,727 & 37.77 & 160.44 & 7.09 \\
\hline Southwest & 80 & 2.83 & 160.39 & 7.81 & 812 & 17.76 & 161.14 & 7.04 \\
\hline Far West & 77 & 2.73 & 160.54 & 6.83 & 16 & .35 & 157.56 & 9.53 \\
\hline \multicolumn{9}{|l|}{$\begin{array}{l}\text { International } \\
\text { Nativity }\end{array}$} \\
\hline Britain & 379 & 13.42 & 158.34 & 6.17 & 9 & .20 & 156.42 & 8.40 \\
\hline Europe & 89 & 3.15 & 155.10 & 5.61 & 3 & .07 & 157.06 & 2.64 \\
\hline Other & 11 & .39 & 157.60 & 3.24 & 18 & .39 & 157.97 & 5.23 \\
\hline Total & 2,824 & 100.00 & & & 4,573 & 100.00 & & \\
\hline
\end{tabular}

Source: See Table 1.

Notes: Stature is in centimeters. Youth age is between ages 15 and 22. The occupation classification scheme is consistent with Ferrie (1997); The following 
geographic classification scheme is consistent with Carlino and Sill (2000): New England= CT, ME, MA, NH, RI and VT; Middle Atlantic= DE, DC, MD, NJ, NY, and PA; Great Lakes= IL, IN, MI, OH, and WI; Plains= IA, KS, MN, MO, NE, ND, and SD; South East= AL, AR, FL, GA, KY, LA, MS, NC, SC, TN, VA, and WV; South West= AZ, NM, OK, and TX; Far West= CA, CO, ID, MT, NV, OR, UT, WA, and WY. Stature difference is average white stature less average black stature.

Table 2 presents black and white female inmates’ height, age, birth decade, and nativity proportions. Although average statures are included, they are not reliable because of possible compositional effects, which are accounted for in the regression models that follow. Whites were a smaller portion of the prison population than blacks; 38 percent of the US female prison population was white. Age percentages demonstrate that black females were incarcerated at younger ages, while whites were incarcerated at older ages. Southern law evolved to favor plantation law, which allowed slave owners to recover slave labor on plantations while slaves were punished (Komlos and Coclanis, 1997, p. 436; Wahl, 1996, 1997; Friedman, 1993). Black females took up larger female proportions after emancipation. However, with passage of the $13^{\text {th }}$ amendment, slave owners no longer had claims on black labor, and free black females who broke the law were turned over to state penal systems to exact their social debt.

3. The Comparative Effects of Demographics, Socioeconomic Characteristics on Black and White Female Statures 
Nineteenth century black and white female statures were related to race, age, birth year, and nativity. We test which of these variables were associated with $19^{\text {th }}$ century US black and white female stature variation.

$$
\text { Cent }_{\mathrm{i}}=\alpha+\sum_{\mathrm{r}=1}^{2} \beta_{\mathrm{r}} \text { Race }_{\mathrm{r}}+\sum_{\mathrm{a}=1}^{14} \beta_{\mathrm{a}} \text { Age }_{\mathrm{i}}+\sum_{\mathrm{b}=1}^{13} \beta_{\mathrm{b}} \text { Birth Decade }_{\mathrm{i}}+\sum_{\mathrm{j}=1}^{10} \beta_{\mathrm{j}} \text { Nativity }_{\mathrm{i}}+\varepsilon_{\mathrm{i}}
$$

Dummy variables are included for black and mulatto complexions. Youth dummy variables are added for ages 14 through 22; adult age dummies are included in ten-year age dummies between their 30s and 60s. Birth decade dummy variables are in ten-year intervals from 1770 and 1899. Nativity dummy variables are included for US regional birth and foreign nativities.

Table 3's model 1 combines both black and white females. Model 2 omits international migration and considers only black and white females who were born in the US. Model 3 regresses white female statures on characteristics, while model 4 does the same for blacks. 
Table 3, National Female Stature Models by Race

\begin{tabular}{|c|c|c|c|c|c|c|c|c|}
\hline & $\begin{array}{l}\text { Model 1, } \\
\text { Total } \\
\text { Sample }\end{array}$ & S.E. & $\begin{array}{l}\text { Model 2, } \\
\text { Non- } \\
\text { Migrants }\end{array}$ & S.E. & $\begin{array}{c}\text { Model 3, } \\
\text { Whites }\end{array}$ & S.E. & $\begin{array}{c}\text { Model 4, } \\
\text { Blacks }\end{array}$ & S.E. \\
\hline $\begin{array}{l}\text { Intercept } \\
\text { Race }\end{array}$ & $162.65 * * *$ & .314 & $162.67 * * *$ & .318 & $163.07 * * *$ & .499 & $161.07 * * *$ & .353 \\
\hline Black & $-1.45 * * *$ & .208 & $-1.48 * * *$ & .210 & & & Reference & \\
\hline Mulatto & $-1.16 * * *$ & .243 & $-1.20 * * *$ & .245 & & & .264 & .218 \\
\hline $\begin{array}{l}\text { White } \\
\text { Ages }\end{array}$ & Reference & & Reference & & Reference & & & \\
\hline 14 & $-7.06 * * *$ & .936 & $-7.05 * * *$ & .935 & $-6.24 * * *$ & 2.46 & $-7.12 * * *$ & .977 \\
\hline 15 & $-3.32 * * *$ & .798 & $-3.33 * * *$ & .819 & $-2.96^{*}$ & 1.75 & $-3.35 * * *$ & .891 \\
\hline 16 & $-2.83 * * *$ & .492 & $-2.80 * * *$ & .493 & $-3.24 * * *$ & 1.12 & $-2.82 * * *$ & .547 \\
\hline 17 & $-1.37 * * *$ & .354 & $-1.35 * * *$ & .360 & $-2.53 * * *$ & .582 & $-1.09 * * *$ & .432 \\
\hline 18 & $-1.26 * * *$ & .318 & $-1.18 * * *$ & .321 & $-1.54 * * *$ & .613 & $-1.20 * * *$ & .375 \\
\hline 19 & $-1.00 * * *$ & .340 & $-1.07 * * *$ & .342 & $-1.26^{*}$ & .689 & $-.895^{* *}$ & .388 \\
\hline 20 & $-.731^{* *}$ & .355 & $-.728 * *$ & .360 & $-1.34^{* *}$ & .672 & -.574 & .421 \\
\hline 21 & $-.594^{*}$ & .355 & $-.631^{*}$ & .361 & -.018 & .678 & $-.883 * *$ & .413 \\
\hline 22 & -.533 & .365 & -.548 & .370 & -.143 & .593 & $-.737^{*}$ & .459 \\
\hline $23-29$ & Reference & & Reference & & Reference & & Reference & \\
\hline $30 \mathrm{~s}$ & $.761 * * *$ & .245 & $.689 * * *$ & .259 & $.872 * *$ & .354 & .562 & .349 \\
\hline $40 \mathrm{~s}$ & .056 & .344 & .115 & .379 & -.055 & .436 & .256 & .572 \\
\hline $50 \mathrm{~s}$ & .846 & .544 & $1.15^{*}$ & .628 & .917 & .696 & .692 & .928 \\
\hline $60 \mathrm{~s}$ & -.630 & .926 & -.400 & .956 & -1.66 & 1.17 & .871 & 1.57 \\
\hline Birtl & & & & & & & & \\
\hline 1770 & $-1.33^{*}$ & .705 & -.383 & .750 & -2.0 & 1.06 & -.688 & 947 \\
\hline 1780 & $-1.12^{*}$ & .655 & -.696 & .709 & $-1.71 * *$ & .861 & -.695 & .993 \\
\hline 1790 & .169 & .492 & .313 & .513 & -.278 & .775 & .552 & .661 \\
\hline 1800 & -.679 & .486 & -.512 & .494 & -.766 & 1.15 & -.417 & .588 \\
\hline 1810 & $-.831^{*}$ & .507 & -.786 & .520 & -.770 & .868 & -.659 & .648 \\
\hline 1820 & $-1.18^{* *}$ & .488 & $-.944^{*}$ & .535 & $-1.56^{* *}$ & .662 & -.869 & .745 \\
\hline 1830 & $-1.15^{* * *}$ & .419 & $-.785 *$ & .474 & $-1.53 * * *$ & .545 & -.800 & .704 \\
\hline 1840 & $-1.01 * * *$ & .348 & $-1.11 * * *$ & .365 & $-1.21 * * *$ & .475 & $-.955^{*}$ & .530 \\
\hline 1850 & $-1.25^{* * *}$ & .323 & $-1.34^{* * *}$ & .329 & $-1.24^{* * *}$ & .463 & $-1.35^{* * *}$ & .452 \\
\hline 1860 & Reference & & Reference & & Reference & & Reference & \\
\hline 1870 & .229 & .284 & .253 & .285 & -.300 & .470 & .458 & .356 \\
\hline 1880 & .115 & .299 & .142 & .301 & .215 & .542 & .138 & .367 \\
\hline 1890 & -.160 & .380 & -.145 & .381 & -.941 & .755 & .180 & .443 \\
\hline & & & & & & & & \\
\hline Northeast & $-1.54^{*}$ & .798 & $-1.58 *$ & .795 & $-1.97 * *$ & .971 & -.762 & 1.41 \\
\hline Middle & $-2.35 * * *$ & .263 & $-2.45 * * *$ & .266 & $-2.32 * * *$ & .416 & $-2.53 * * *$ & .379 \\
\hline Great Lakes & -.307 & .315 & -.318 & .315 & -.423 & .466 & -.525 & .476 \\
\hline Plains & .281 & .304 & .284 & .304 & -.173 & .522 & .518 & .383 \\
\hline Southeast & Reference & & Reference & & Reference & & Reference & \\
\hline
\end{tabular}




\begin{tabular}{l|cccccccc}
\hline Southwest & .404 & .287 & .403 & .287 & $-1.96^{* *}$ & .928 & $.643^{* *}$ & .3045 \\
Far West & $-2.09 * * *$ & .770 & $-2.09 * * *$ & .771 & $-1.99 * *$ & .847 & -3.28 & 2.19 \\
International & & & & & & & & \\
Nativity & & & & & & & & \\
Europe & $-6.52^{* * *}$ & .650 & & & $-6.75^{* * *}$ & .722 & $-3.45^{* *}$ & 1.35 \\
British & $-3.56^{* * *}$ & .425 & & & $-3.68^{* * *}$ & .513 & -4.17 & 2.75 \\
Other & $-2.84 * * *$ & .828 & & & $-4.20^{* * *}$ & 1.11 & $-1.97 *$ & 1.14 \\
International & & & & & & & & \\
$\mathrm{N}$ & 7,397 & & 6,885 & & 2,824 & & 4,573 & \\
$\mathrm{R}^{2}$ & .0781 & & .0727 & & .0887 & & .0756 & \\
\hline $\mathrm{F}$ & 18.00 & & 16.46 & & 9.20 & & 10.72 & \\
\hline
\end{tabular}

Source: See Table 1.

Notes: See Table 2 notes for birth classification.

Three paths of enquiry are considered when comparing $19^{\text {th }}$ century black and white female statures. First, black and white female statures varied by nativity, and after controlling for other variables, white Southeastern and black Southwestern females were taller than their counterparts from elsewhere within the US (Table 3). Part of the Southern stature advantage was related to Southern agriculture. The $19^{\text {th }}$ century opening of the New South to agriculture increased Southern agricultural productivity, which was higher than elsewhere within the US (Higgs, 1977, p. 24; Margo and Steckel, 1982, p. 519; Komlos and Coclanis, 1997, p. 443). Before the Civil War, the South was selfsufficient in food production and relatively high white wages may have also influenced Southern white female statures (Fogel, 1994, pp. 89, 132-133). After the Civil War, Southern wages in the West South Central were in general lower than Midwest wages and comparable to those in the Middle Atlantic region. Black females from the Great Lakes were taller than black females from the Northeast and Plains. US born females were also taller than their British and European-born counterparts. 
Second, it is striking the degree to which white female statures exceed black statures, which is significant because modern black and white statures have the ability to reach comparable levels when brought to maturity under similar biological conditions (Eveleth and Tanner, 1976; Tanner, 1977; Steckel 1995, p. 1910; Barondess et al., 1997, p. 968; Komlos and Baur, 2004, pp. 64 and 69; Nelson et al., 1993, pp. 18-20; Godoy et al., 2005, pp. 472-473; Margo and Steckel, 1982, p. 519). Moreover, compositional effects can not explain the black-white stature differential, which was due, in part, to whites' access to meat and better nutrition (Margo and Steckel, 1982 pp. 514-515, 517, and 519). Much has also been written about the $19^{\text {th }}$ century male mulatto stature advantage, and mulatto females may have been taller than their darker complexioned counterparts, indicating that, although it was less pronounced, there may have been a $19^{\text {th }}$ century US female mulatto stature advantage (Steckel, 1979; Bodenhorn, 1999 and 2001; Carson, 2008 and 2009).

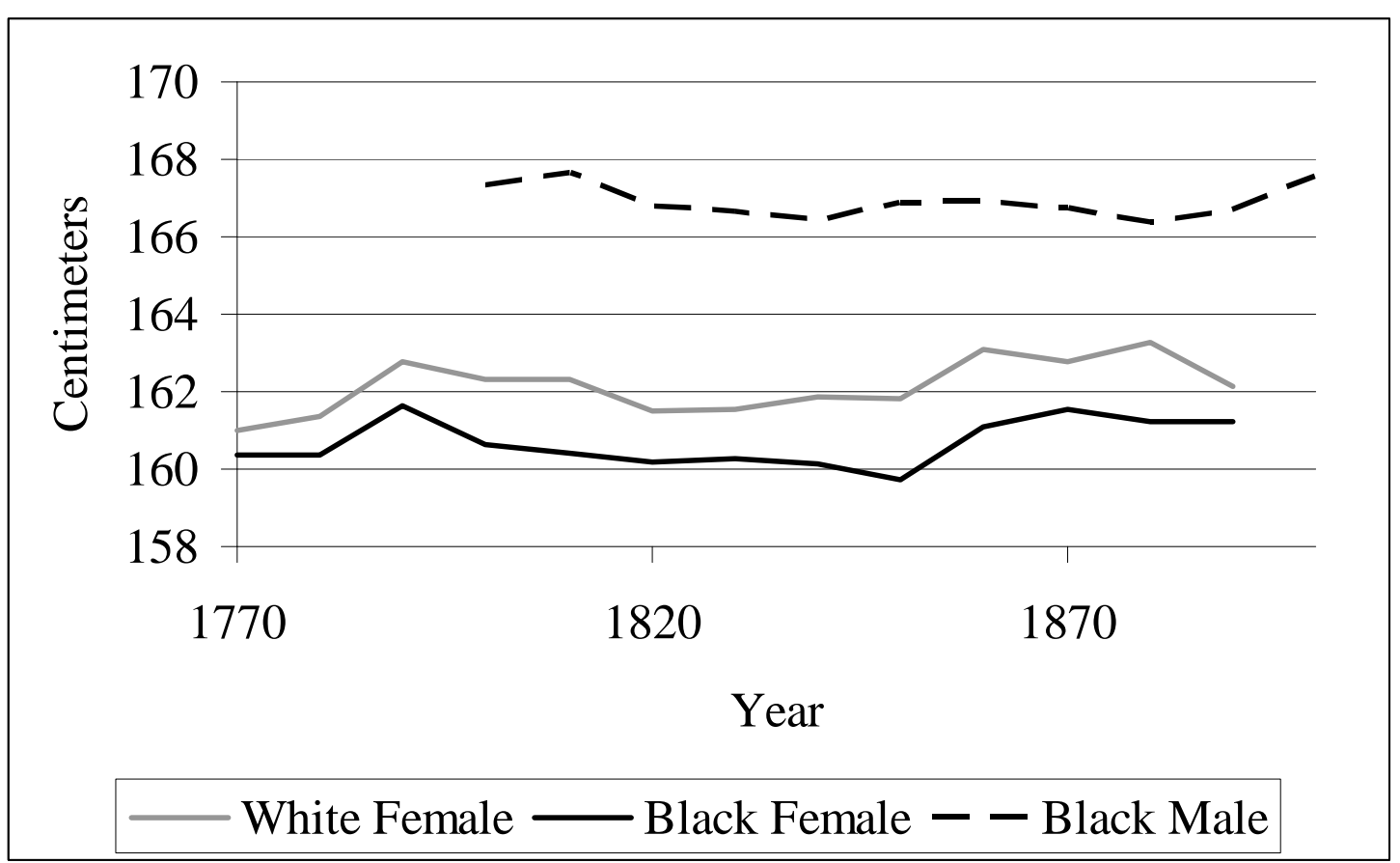


Figure 2, Nineteenth Century Black and White Female Stature Variation by Birth Period Source: See Table 3, Models 3 and 4. Black male statures are from Carson (2008).

Third, black and white female statures varied considerably over the course of the $19^{\text {th }}$ century (Figure 2). Between 1770 and 1810 , white female statures increased by over one $\mathrm{cm}$. Although black female statures increased between 1770 and 1790 , the late $18^{\text {th }}$ century black female stature decline began earlier than for early $19^{\text {th }}$ century white females. Between 1820 and 1850, both black and white female statures stagnated (Komlos, 1992, p. 311). This $19^{\text {th }}$ century black female stature decline is even more striking compared to black male statures over the same period. Between 1840 and 1860, black male statures increased by nearly one $\mathrm{cm}$, indicating that black females probably did not share in the late antebellum prosperity experienced by black males (Carson, 2008, pp. 822-825; Carson, 2009, pp. 154-157). Similar to the trend in black male statures, white female statures increased in the decade prior to the Civil War and declined once the institution of slavery was eliminated (Carson, 2009, p. 154), indicating that the economic and biological disruptions created by the removal of slavery fell on Southern females. The 1890's white female stature decline also corresponds with the 1890's economic turmoil, and statures are related with stages of the business cycle (Woitek, 2003). To sustain farm production as economic and nutritional conditions varied, households reallocated nutritional allotments to males who were engaged in agricultural production, and black and white female biological living conditions disproportionately experienced the sting of $19^{\text {th }}$ century US economic development. Female stature variation, therefore, 
suggests that $19^{\text {th }}$ century female statures and health bore the brunt of US industrialization.

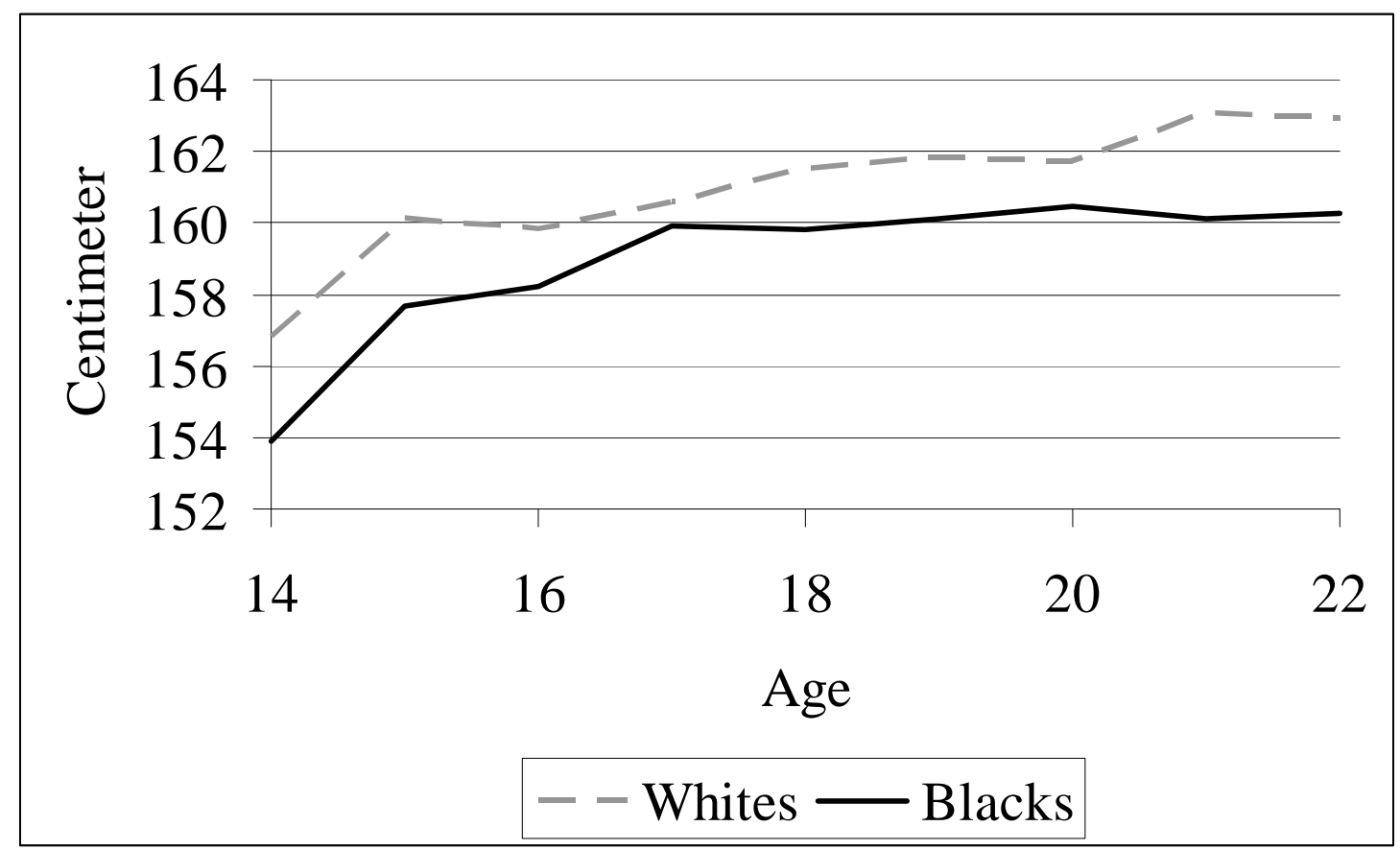

Figure 3, Nineteenth Century Black and White Female Stature Variation by Age Source: See Table 3, Models 3 and 4.

Other patterns are consistent with expectations, and the youth height pattern by age is itself noteworthy. Stature is related to age, and delayed adult stature is a sign of inferior biological conditions (Figure 3). The relationship is further complicated by sexual dimorphism between males and females, and although females reach shorter terminal statures, female teen growth spurts begin earlier than males and end about 18 months earlier (Tanner, 1977). We, therefore, expect that young adult female terminal 
statures are reached between 17 and 19 years old. ${ }^{3}$ Nineteenth century female statures increased rapidly with age in their early teen years, and black female statures reached adult terminal statures by age 17, which is comparable to that found by Komlos (1992). However, white female statures continued to increase into their 20s, suggesting that $19^{\text {th }}$ century black females reached terminal statures by their late teens, while young white female stature growth continued into their 20 s. Therefore, $19^{\text {th }}$ century female stature variation was the result of a complex set of demographic, nativity, and socioeconomic characteristics, and female stature variation was similar to the lowest socioeconomic status $19^{\text {th }}$ century males.

\section{Conclusion}

Nineteenth century males reached taller statures than females, and because females did not serve in the military or commit a sufficient number of crimes to produce sufficiently large samples of females, $19^{\text {th }}$ century female stature studies have been slow to emerge. This project, however, collects female statures from several $19^{\text {th }}$ century US state penitentiaries and sheds new light on the status of $19^{\text {th }}$ century black and white female biological living conditions during industrialization. First, white Southeastern and black Southwestern female statures were taller than elsewhere within the US and internationally, suggesting superior biological environments that accrued to North American females. Second, like male statures, white females were taller than black females, and there is limited evidence of a $19^{\text {th }}$ century female mulatto stature advantage. Third, black and white female statures varied throughout the $19^{\text {th }}$ century industrialization, emancipation, and were similar to stature variation experienced by the

\footnotetext{
${ }^{3}$ Males typically reach taller terminal statures than females between 18 and 21 years of age.
} 
lowest segment of $19^{\text {th }}$ century male society, indicating that $19^{\text {th }}$ century females disproportionately experienced biological disruption during economic development. Therefore, $19^{\text {th }}$ century black and white female stature variation was the result of a complex set of socioeconomic variables, and female stature variation was similar to the stature variation among the lowest male African-American economic and social class. 


\section{References}

Atack, Jeremy and Fred Batman (1980) “The ‘Egalitarian Ideal’ and the Distribution of Wealth in the Northern Agricultural Community: a Backward Look.” Review of Economics and Statistics, 63: 124-129.

Atack, Jeremy and Fred Bateman, To Their Own Soil: Agriculture in the Antebellum North. Ames, Iowa: Iowa State University Press, 1987.

Barondess, D. A. Nelson, D A., \& Schlaen, S. E., (1997) “Whole Body

Bone, Fat and Lean Mass in Black and White Men,” Journal of Bone and Mineral Research, 12, 967-971.

Bodenhorn, Howard. “A Troublesome Caste: Height and Nutrition of Antebellum Virginia’s Rural Free Blacks.” Journal of Economic History. 59, no. 4 (December, 1999): 972-996.

Bogin, Barry, 1991, “Measurement of Growth Variability and Environmental Quality in Guatemalan Children,” Annals of Human Biology 18, pp. 285-294.

Carson, S. (2008). The Effects of Geography and Vitamin D on African American Stature in the $19^{\text {th }}$ Century: Evidence from Prison Records, Journal of Economic History, 68, 812-831.

Carson SA. (2009). “Geography, Insolation, and Vitamin D in $19^{\text {th }}$ Century US AfricanAmerican and White Statures.” Explorations in Economic History 46:149-159. Case, Ann and Christina Paxson (2008), “Height, Health, and Cognitive Function at Older Ages”, American Economic Review 98: 463-467.

Easterlin, Richard. “Regional Income Trends, 1840-1950.” in The Reinterpretation of 
American Economic History, edited Robert Fogel and Stanley

Engerman. New York: Harper \& Row. 1971. 38-53.

Deaton, Angus (2008) “Height, Health, and Inequality: The Distribution of Adult

Heights in India”, American Economic Review 98: 468-474.

Eveleth, Phillis B. and James M. Tanner. Worldwide Variation in Human Growth.

Cambridge: Cambridge University Press. 1976. Second Ed. 1990.

Floud, Rodrick., Wachter, Kenneth. and A. Gregory (1990) Height, Health and History:

Nutritional Status in the United Kingdom, 1750-1980. Cambridge: Cambridge University Press.

Fogel, Robert W. "Economic Growth, Population Theory and Physiology: The Bearing of Long-Term Processes on the Making of Economic Policy,” American Economic Review 84(3), 1994, pp. 369-395.

Fogel, Robert, Stanley Engerman, James Trussell, Roderick Floud, Clayne Pope, and Larry Wimmer, "Economics of Mortality in North America, 1650-1910: A

Description of a Research Project,” Historical Methods, 11(2), 1978, pp. 75-108.

Friedman, Lawrence M. Crime and Punishment in American History. New York: Basic Books , 1993.

Godoy, R., Goodman, E., Levins, R., \& Leonard, W.R. (2005) “Anthropometric Variability in the USA,” Annals of Human Biology32, 469-485.

Higgs, Robert. Competition and Coercion. Chicago: University of Chicago Press, 1977. Komlos, John. "Stature and Nutrition in the Habsburg Monarchy: The Standard of Living and Economic Development in the Eighteenth Century." American Historical Review. 90, no. 5 (November, 1985): 1149-61. 
Komlos, John. “The Height and Weight of West Point Cadets: Dietary Change in Antebellum America.” Journal of Economic History 47, no. 4 (December 1987): 897-927.

Komlos, John. "Toward an Anthropometric History of African-Americans: The Case of the Free Blacks in Antebellum Maryland.” in Strategic Factors in Nineteenth Century American Economic History: A Volume to Honor Robert W. Fogel, edited by Claudia Goldin and Hugh Rockoff. Chicago: University of Chicago Press. 1992, 297-329.

Komlos, John and Peter Coclanis. “On the Puzzling Cycle in the Biological Standard of Living: The Case of Antebellum Georgia.” Explorations in Economic History. 34, no. 4 (October, 1997): 433-59.

Komlos, John and Jörg Baten (2004) “Anthropometric Research and the Development of Social Science History. Social Science History. 28: 191-210.

Komlos, John and Marieluise Baur, "From Tallest to (one of) the Fattest: the Enigmatic Fate of American Population in the $20^{\text {th }}$ Century.” Economics and Human Biology 2, no. 1 (March, 2004): 57-74.

Margo, Robert, 2000, Wages and Labor Markets in the United States, 1820-1860. Chicago: University of Chicago Press.

Margo, Robert and Richard Steckel. "Heights of American Slaves: New Evidence on Nutrition and Health.” Social Science History 6, no. 4 (Fall, 1982): 516-538. Margo, Robert, and Richard H. Steckel (1983) “Heights of Native Born Northern Whites during the Antebellum Era.” Journal of Economic History 43: 167-174.

Nelson, D., Kleerekoper, M., Peterson E. \& A. M. Parfitt, (1993) “Skin Color and 
Body Size as Risk Factors for Osteoporosis,” Osteoporosis International, 3, $18-23$.

Nicholas, Stephen and Richard Steckel, "Heights and Living Standards of English Workers During the Early Years of Industrialization.” Journal of Economic History. 51(4), 1991, pp. 937-957.

Sokoloff, K. \& Villaflor, G. (1982) “Early Achievement of Modern Stature in America,” Social Science History 6, 453-481.

Soltow, Lee (1975) Men and Wealth in the United States, 1850-1870. New Haven: Yale University Press.

Steckel, Richard, 1979, “Slave Height Profiles from Coastwise Manifests,” Explorations in Economic History 16, pp. 363-380.

Steckel, Richard (1983) “Height and Per Capita Income,” Historical Methods, 16: 1-7.

Steckel, Richard, 1986 “A Peculiar Population: the Nutrition, Health and Mortality of American Slaves from Childhood through Mortality,” Journal of Economic History, 46, pp. 721-41.

Steckel, R. (1992) Work Disease and Diet in the Health and Mortality of American Slaves. In: Fogel, R. W., (ed.) Without Consent or Contract: Conditions of Slave Life and the Transition to Freedom. Norton, New York, 489-507.

Steckel, Richard H. (1995) “Stature and the Standard of Living.” Journal of Economic Literature 33, 1903-1940.

Stauss, John and Duncan Thomas (1998), “Health, Nutrition, and Economic Development.” Journal of Economic Literature, 36: 766-817. 
Sunder, Marco (2004) “The Height of Tennessee Convicts: Another Pieces of the “Antebellum Puzzle”. Economics and Human Biology. pp. 75-86.

Tanner, J. M. (1977). Hormonal, Genetic and Environmental Factors Controlling Growth. In G.A. Harrison, J.S. Weiner, J.M. Tanner \& N.A. Barnicot, (eds.) Human Biology: an Introduction to Human Evolution, Variation, Growth and Ecology, $2^{\text {nd }}$ Ed. (pp. 335-351). Oxford: Oxford University Press.

Wahl, Jenny Bourne, 1996, “The Jurisprudence of American Slave Sales,” The Journal of Economic History, 56(1), pp. 143-169.

Wahl, Jenny Bourne, 1997, “Legal Constraints on Slave Masters: the Problem of Social Cost,” The American Journal of Legal History, 1997, pp. 1-24.

Williamson, Jeffrey and Peter Lindert, 1980, American Inequality: A Macroeconomics History. Academic Press: London.

Woitek, Ulrich, (2003), "Height Cycles in the $18^{\text {th }}$ and $19^{\text {th }}$ Centuries." Economics and Human Biology 1(2), pp. 243-257. 


\section{CESifo Working Paper Series}

for full list see www.cesifo-group.org/wp

(address: Poschingerstr. 5, 81679 Munich, Germany, office@cesifo.de)

3107 Jenny E. Ligthart and Gerard C. van der Meijden, Coordinated Tax-Tariff Reforms, Informality, and Welfare Distribution, June 2010

3108 Vilen Lipatov and Alfons Weichenrieder, Optimal Income Taxation with Tax Competition, June 2010

3109 Malte Mosel, Competition, Imitation, and R\&D Productivity in a Growth Model with Sector-Specific Patent Protection, June 2010

3110 Balázs Égert, Catching-up and Inflation in Europe: Balassa-Samuelson, Engel's Law and other Culprits, June 2010

3111 Johannes Metzler and Ludger Woessmann, The Impact of Teacher Subject Knowledge on Student Achievement: Evidence from Within-Teacher Within-Student Variation, June 2010

3112 Leif Danziger, Uniform and Nonuniform Staggering of Wage Contracts, July 2010

3113 Wolfgang Buchholz and Wolfgang Peters, Equity as a Prerequisite for Stable Cooperation in a Public-Good Economy - The Core Revisited, July 2010

3114 Panu Poutvaara and Olli Ropponen, School Shootings and Student Performance, July 2010

3115 John Beirne, Guglielmo Maria Caporale and Nicola Spagnolo, Liquidity Risk, Credit Risk and the Overnight Interest Rate Spread: A Stochastic Volatility Modelling Approach, July 2010

3116 M. Hashem Pesaran, Predictability of Asset Returns and the Efficient Market Hypothesis, July 2010

3117 Dorothee Crayen, Christa Hainz and Christiane Ströh de Martínez, Remittances, Banking Status and the Usage of Insurance Schemes, July 2010

3118 Eric O'N. Fisher, Heckscher-Ohlin Theory when Countries have Different Technologies, July 2010

3119 Huw Dixon and Hervé Le Bihan, Generalized Taylor and Generalized Calvo Price and Wage-Setting: Micro Evidence with Macro Implications, July 2010

3120 Laszlo Goerke and Markus Pannenberg, 'Take it or Go to Court' - The Impact of Sec. 1a of the German Protection against Dismissal Act on Severance Payments -, July 2010

3121 Robert S. Chirinko and Daniel J. Wilson, Can Lower Tax Rates be Bought? Business Rent-Seeking and Tax Competition among U.S. States, July 2010 
3122 Douglas Gollin and Christian Zimmermann, Global Climate Change and the Resurgence of Tropical Disease: An Economic Approach, July 2010

3123 Francesco Daveri and Maria Laura Parisi, Experience, Innovation and Productivity Empirical Evidence from Italy's Slowdown, July 2010

3124 Carlo V. Fiorio and Massimo Florio, A Fair Price for Energy? Ownership versus Market Opening in the EU15, July 2010

3125 Frederick van der Ploeg, Natural Resources: Curse or Blessing?, July 2010

3126 Kaisa Kotakorpi and Panu Poutvaara, Pay for Politicians and Candidate Selection: An Empirical Analysis, July 2010

3127 Jun-ichi Itaya, Makoto Okamura and Chikara Yamaguchi, Partial Tax Coordination in a Repeated Game Setting, July 2010

3128 Volker Meier and Helmut Rainer, On the Optimality of Joint Taxation for NonCooperative Couples, July 2010

3129 Ryan Oprea, Keith Henwood and Daniel Friedman, Separating the Hawks from the Doves: Evidence from Continuous Time Laboratory Games, July 2010

3130 Mari Rege and Ingeborg F. Solli, The Impact of Paternity Leave on Long-term Father Involvement, July 2010

3131 Olaf Posch, Risk Premia in General Equilibrium, July 2010

3132 John Komlos and Marek Brabec, The Trend of BMI Values by Centiles of US Adults, Birth Cohorts 1882-1986, July 2010

3133 Emin Karagözoğlu and Arno Riedl, Information, Uncertainty, and Subjective Entitlements in Bargaining, July 2010

3134 John Boyd, Gianni De Nicolò and Elena Loukoianova, Banking Crises and Crisis Dating: Theory and Evidence, July 2010

3135 Michael R. Baye, Dan Kovenock and Casper G. de Vries, The Herodotus Paradox, July 2010

3136 Martin Kolmar and Hendrik Rommeswinkel, Group Contests with Complementarities in Efforts, July 2010

3137 Carolina Manzano and Xavier Vives, Public and Private Learning from Prices, Strategic Substitutability and Complementarity, and Equilibrium Multiplicity, July 2010

3138 Axel Löffler, Gunther Schnabl and Franziska Schobert, Inflation Targeting by Debtor Central Banks in Emerging Market Economies, July 2010 
$3139 \mathrm{Yu}-\mathrm{Fu}$ Chen and Michael Funke, Global Warming and Extreme Events: Rethinking the Timing and Intensity of Environmental Policy, July 2010

3140 Lawrence M. Kahn, Labor Market Policy: A Comparative View on the Costs and Benefits of Labor Market Flexibility, July 2010

3141 Ben J. Heijdra, Jochen O. Mierau and Laurie S.M. Reijnders, The Tragedy of Annuitization, July 2010

3142 Erkki Koskela, Outsourcing Cost and Tax Progression under Nash Wage Bargaining with Flexible Outsourcing, July 2010

3143 Daniel Osberghaus and Christiane Reif, Total Costs and Budgetary Effects of Adaptation to Climate Change: An Assessment for the European Union, August 2010

3144 Philip E. Graves, Benefit-Cost Analysis of Environmental Projects: A Plethora of Systematic Biases, August 2010

3145 Sabrina Di Addario and Daniela Vuri, Entrepreneurship and Market Size. The Case of Young College Graduates in Italy, August 2010

3146 Shoshana Amyra Grossbard and Alfredo Marvăo Pereira, Will Women Save more than Men? A Theoretical Model of Savings and Marriage, August 2010

3147 Jarko Fidrmuc, Time-Varying Exchange Rate Basket in China from 2005 to 2009, August 2010

3148 Ilja Neustadt and Peter Zweifel, Is the Welfare State Sustainable? Experimental Evidence on Citizens' Preferences for Redistribution, August 2010

3149 Marcus Dittrich and Andreas Knabe, Wage and Employment Effects of Non-Binding Minimum Wages, August 2010

3150 Shutao Cao, Enchuan Shao and Pedro Silos, Fixed-Term and Permanent Employment Contracts: Theory and Evidence, August 2010

3151 Ludger Woessmann, Cross-Country Evidence on Teacher Performance Pay, August 2010

3152 Lorenzo C. G. Pozzi, Casper G. de Vries and Jorn Zenhorst, World Equity Premium Based Risk Aversion Estimates, August 2010

3153 Volker Grossmann, Thomas M. Steger and Timo Trimborn, Dynamically Optimal R\&D Subsidization, August 2010

3154 Alexander Haupt, Tim Krieger and Thomas Lange, A Note on Brain Gain and Brain Drain: Permanent Migration and Education Policy, August 2010

3155 António Afonso and Christophe Rault, Long-run Determinants of Sovereign Yields, August 2010 
3156 Franziska Tausch, Jan Potters and Arno Riedl, Preferences for Redistribution and Pensions. What can we Learn from Experiments?, August 2010

3157 Martin Kolmar and Andreas Wagener, Inefficient Group Organization as Optimal Adaption to Dominant Environments, August 2010

3158 Kai Carstensen, Klaus Wohlrabe and Christina Ziegler, Predictive Ability of Business Cycle Indicators under Test: A Case Study for the Euro Area Industrial Production, August 2010

3159 Horst Rottmann and Timo Wollmershäuser, A Micro Data Approach to the Identification of Credit Crunches, August 2010

3160 Philip E. Graves, Appropriate Fiscal Policy over the Business Cycle: Proper Stimulus Policies Can Work, August 2010

3161 Michael Binder and Marcel Bluhm, On the Conditional Effects of IMF Program Participation on Output Growth, August 2010

3162 Michael Binder, Qianying Chen, and Xuan Zhang, On the Effects of Monetary Policy Shocks on Exchange Rates, August 2010

3163 Felix J. Bierbrauer, On the Optimality of Optimal Income Taxation, August 2010

3164 Nikolaus Wolf, Europe's Great Depression - Coordination Failure after the First World War, September 2010

3165 Dan Kovenock and Brian Roberson, Conflicts with Multiple Battlefields, September 2010

3166 Jean-Pierre Ponssard and Catherine Thomas, Capacity Investment under Demand Uncertainty. An Empirical Study of the US Cement Industry, 1994-2006, September 2010

3167 Jørgen Juel Andersen, Jon H. Fiva and Gisle James Natvik, Voting when the Stakes are High, September 2010

3168 Michael Hoel, Is there a Green Paradox?, September 2010

3169 Scott Alan Carson, Nineteenth Century US African-American and White Female Statures: Insight from US Prison Records, September 2010 